\title{
LEPTIN, OBESITY PARAMETERS, AND ATOPY AMONG CHILDREN WITH ASTHMA
}

\author{
Valentina Cvejoska Cholakovska ${ }^{1}$, Emilija Vlashki ${ }^{1}$, \\ Mirjana Kochova ${ }^{2}$, Vesna Velikj Stefanovska ${ }^{3}$, Aleksandar Petlichkovski ${ }^{4}$ \\ ${ }^{1}$ Department of Pulmonology and Allergology, University Children's Clinic, Faculty of Medicine, Sts. Cyril and Methodius \\ University in Skopje, N Macedonia \\ ${ }^{2}$ Department of Endocrinology and Genetics, University Children's Clinic, Faculty of Medicine, Sts. Cyril and Methodius Uni- \\ versity in Skopje, N Macedonia \\ ${ }^{3}$ Institute of Epidemiology and Biostatistics, Faculty of Medicine, Sts. Cyril and Methodius University in Skopje, North Macedonia \\ ${ }^{4}$ Institute for Immunobiology and Human Genetics, Faculty of Medicine, Sts. Cyril and Methodius University in Skopje, N \\ Macedonia
}

Corresponding author: Valentina Cvejoska Cholakovska, University Children's Hospital, North Macedonia, vcolakovska@yahoo.com

\section{ABSTRACT}

Leptin, as a major adipokine, positively correlates with the body's fat, while atopy is an important feature in the development of childhood asthma. We aimed to evaluate the relationship between leptin, parameters of obesity, and atopy in children with asthma. The study included 112 children ( 73 boys, 39 girls, mean age 11.1 \pm 2.4 ). 41 were overweight, 38 had asthma and a normal body mass index (BMI), and 33 were overweight asthmatics. Serum leptin levels, BMI, waist circumference (WC), and waist to hips ratio (WHR) were measured. Skin prick test (SPT)/CAP, total serum IgE, fractional exhaled nitric oxide (FeNO), and pulmonary function tests were performed. In asthmatic children, serum leptin median level was $9.2 \pm 16.2$ $\mathrm{ng} / \mathrm{ml}$, in overweight children was $30.6 \pm 21.6 \mathrm{ng} / \mathrm{ml}$, and in overweight asthmatics was $31.1 \pm 20.3 \mathrm{ng} / \mathrm{ml}$ with a significant difference between the groups $(\mathrm{p}=0.0374)$, yet with a significantly lower median level in the group of children with asthma compared to the overweight children: with asthma $(p=0.00001)$ and without asthma $(\mathrm{p}=0.00001)$. In the three groups of patients, $\mathrm{BMI}$ and $\mathrm{WC}$ displayed a significant positive correlation with leptin (for BMI $r=0.652$ vs. $r=0.530$ vs. $r=0.563$, respectively and for $\mathrm{WC} r=0.508$ vs. $\mathrm{r}=0.426$ vs. $\mathrm{r}=0.527$, respectively). No significant correlations of leptin within atopy parameters (Eo, $\operatorname{IgE}$, $\mathrm{SPT} / \mathrm{CAP}, \mathrm{FeNO})$ in all three analyzed groups $(\mathrm{p}>0.05)$ was detected.

Conclusion: Atopy was not confirmed as an underlying mechanism of the association between asthma and being overweight. Leptin had a significant linear correlation as a parameter of central obesity with BMI and WC in all three groups, but not with WHR.

Keywords: Asthma, body mass index, children, obesity, overweight, leptin

\section{INTRODUCTION}

With more than 339 million asthmatics worldwide, asthma is one of the most common chronic diseases, with a rising prevalence recently among low-income and middle-income countries. Its prevalence is increasing especially among various groups of children. [1] In Macedonia, during the period of 2002-2004, within the framework of the International Study of Asthma and Allergies in Childhood (ISAAC), a low prevalence of asthma was reported. It is probable that 
this was due to an under-diagnosis of this disease [2], however as in other low-income countries, the prevalence of asthma has increased over the last two decades. [3, 4]

Obesity is also a global public health problem, with more than 1.9 billion people overweight, and about 650 million obese adults worldwide. Being overweight is also a health problem with children and the prevalence among them is increasing at an alarming rate. [5] The ISAAC study in Macedonia reported a moderately low prevalence of overweight and a low prevalence of obesity. [4] Thirteen years on, a significantly higher prevalence has been documented of overweight/ obese children aged 5 to 15 years. [6]

Although a parallel epidemic of asthma and obesity has broken out worldwide over the course of the last few decades, their association is still being investigated. They are likely connected in a multifactorial etiopathogenesis. Although genetic susceptibility can contribute to the development of both asthma and obesity, the rapid increase in a relatively short period suggests that changes in lifestyle, such as diet, physical activity, early life exposure to allergens, and other environmental interactions, can play an important role. Epigenetic mechanisms associated with obesity and asthma have been proposed. [7] The physical and mechanical effects of obesity on the respiratory system likely play a part in the connection between childhood obesity and asthma. Obesity affects how the lungs function in adults, with and without asthma. [8] The most consistent data show a decrease in functional residual capacity and lower tidal volumes, primarily because of changes in the elastic properties of the chest wall. Increased systemic inflammation has also been reported as a possible link between childhood asthma and obesity [9]. Obesity is associated with an excess of adipose tissue and a low-grade systemic inflammation, giving a rise to the idea that it is a "pro-inflammatory state." [10] Leptin levels in circulation show a positive correlation with body mass index (BMI) and reflect body fat mass. [11] BMI is an indicator most commonly used to determine the nutritional condition of an individual. There are studies that suggest an connection between obesity and asthma, but very little is known about the role of leptin in children with asthma as a chronic inflammatory disease.

The aim of this study was to evaluate the serum leptin level in children with asthma and to examine any correlation between leptin and parameters of obesity - BMI, WC and WHR as well as the parameters of atopy.

\section{MATERIAL AND METHODS}

The study was performed in 2019 at the University Children's Clinic in Skopje, the capital of the R. N. Macedonia. The sample consists of 112 children, aged 7-17 years, treated as outpatient or inpatient and were categorized in three groups as: overweight, asthma, or overweight+asthma. Forty one were overweight, 38 had asthma and a normal BMI, and 33 had asthma and were overweight. Exclusion criteria were the presence of other diseases, obesity due to other conditions, and administration of systemic corticosteroid therapy three months before being included in the study. A medical history was taken from every child's parents and then each child was examined.

In each child, leptin was determined via Luminex technology. Blood samples were obtained early in the morning after an overnight fast. After clotting at $4{ }^{\circ} \mathrm{C}$, the serum was separated by centrifugation and stored at $-80^{\circ} \mathrm{C}$ until the assay. The sample was added to a mixture of color-coded beads, pre-coated with leptin specific antibodies. Biotinylated detection antibodies specific to leptin were added and formed an antibody-antigen sandwich. The beads were read on a dual-laser flow-based detection instrument Luminex 200TM. All standards and recommendations were observed in accordance with the manufacturer's instructions, Immuno-Biological Laboratories (IBL) (Hamburg, Germany). Reference values for leptin by sex and age in $\mathrm{ng} / \mathrm{ml}$ were used. [12]

BMI was calculated as body weight $(\mathrm{kg})$ / body height $(\mathrm{m})^{2}$, using the international reference values for sex and age, defining overweight for those over $25 \mathrm{~kg} / \mathrm{m}^{2}$ and obesity for those above $30 \mathrm{~kg} / \mathrm{m}^{2}$ at 18 years of age. [13] For abdominal obesity assessment, WC was measured in centimeters between the lower border of the ribcage and mid line of the iliac crest, as well as the hip circumference (HC) was measured in centimeters from the widest point of the hips, and then WHR was calculated. [14] Reference values by sex and age were used, defining abdominal obesity as over 90th percentile. [15] 
SPT was performed with commercial inhalant allergen extracts such as dermatophagoides pteronyssinus, dermatophagoides farinae, a mixture of grass pollen, a mixture of tree pollen, cat epithelium, dog epithelium, mold, and cockroach. Tests were performed on the volar side of the forearm using commercial allergenic extract (Allergopharma, Germany). For positive control, $1 \mathrm{mg} / \mathrm{ml}$ of histamine and for negative control saline were used. The tests were interpreted 15 minutes after administration of allergen extracts, in comparison with the histamine and the saline reaction. For in vitro total and specific IgE antibody values, Immulite 2000 Systems Analyzers were used via a chemiluminescent immunoassay technique, according to the manufacturer's instructions (Lianberis, Gwynedd, United Kingdom). Referent values for total (IU/ml) and specific IgE-antibodies ( $\mathrm{kU} / \mathrm{L}$ ) were defined by sex and age. [16, 17] Atopy was defined as a positive response to one or more aeroallergens and/or with high IgE levels. [18]

The assessment of pulmonary function was performed with a Schiller SP-1 spirometer. $[19,20]$ The spirometric parameters of FEV1, FVC, FEV1 / FVC ratio or Tiffeneau index, were investigated. The results were then expressed in percent of predictive value for gender and age. [21] Spirometric measurements were repeated 15 minutes after administration of $200 \mathrm{mg}$ salbutamol (albuterol) through a metered-dose inhaler and a Volumatic spacer device. A $12 \%$ increase in FEV1 over the baseline was considered as a significant bronchodilator response.

The assessment of eosinophilic airway inflammation was realized by measuring $\mathrm{Fe}(\mathrm{NO})$, using a NO analyzer Niox Vero (Uppsala, Sweden). After maximum inspiration, the patients exhaled air without prior retention, at a speed of $50 \mathrm{~m} / \mathrm{s}$. Values $<20 \mathrm{ppb}$ in childhood indicates a non-eosinophilic airway inflammation, or a stable clinical condition. [22]

Potential confounding factors such as a family history of atopy, passive smoking exposure, birth weight, and duration of breast-feeding, were also evaluated by using a questionnaire.

The study was approved by the Ethics Committee at the Medical Faculty in Skopje. Each parent/guardian signed an informed consent form for their respective child patient included in the study.

Statistical analysis was performed with SPSS 22.0 (SPSS, Chicago, IL, USA). The qualitative series were processed by determin- ing the coefficient of relations, proportions, and rates. These were shown as absolute and relative numbers. Quantitative series were analyzed with measures of central tendency (average, median), as well as with dispersion measures (standard deviation, standard error). The distribution of frequencies was analyzed through the Shapiro-Wilk test. The Pearson Chi square, Yates corrected, Fischer exact, and Fisher Freeman Halton exact tests were used to determine the association between certain attributive variables. To test the significance of the difference between certain analyzed parameters, depending on the frequency distribution, Student's t-test, One Way ANOVA test, Mann Whitney U test and the Kruskal-Wallis H test were used. A two-sided analysis with a significance level of $p<0.05$ was used to determine the statistical significance.

\section{RESULTS}

The study included 112 children, aged 7-17 years, who were divided in three groups, 41 $(36.6 \%)$ children with high BMI - Overweight group, $38(33.9 \%)$ children with asthma and normal BMI - Asthma group and 33 (29.5\%) children with asthma and high BMI - Overweight + Asthma group. The clinical characteristics of the children are summarized in Table 1.

The mean values for age did not show any differences between the groups. There was no significant association between sex, premature birth, and breast-feeding within the groups. Familial atopy was significantly more associated with Asthma as well Overweight + Asthma compared to Overweight [OR=3.937 $(1.46-10.61)$ $95 \% \mathrm{CI}]$ vs $[\mathrm{OR}=5.880(1.89-18.23) 99 \% \mathrm{CI}]$, respectively. No significant difference between Asthma and Overweight+Asthma groups regarding familial atopy was found $(\mathrm{p}=0.5214)$. We found the familial history of diabetes mellitus was associated significantly more only with Overweight+Asthma, compared to Asthma $[\mathrm{OR}=3.5294$ (1.25-9.95) 95\%CI]. No percentage difference was found between the groups related to the birth weight $\geq 3.500 \mathrm{~g}$, although the proportion of patients with this birth weight in Overweight as well as Overweight+Asthma group was higher compared to Asthma group. Mean number of family smokers was not significantly different between the groups $(\mathrm{p}=0.0994)$. 
The results of the analysis of leptin and parameters of atopy in the three groups of patients are shown in Table 2.

We did not find any significant difference between the groups related to FEV1/VC. The levels of eosinophils and $\mathrm{IgE}$ in the Overweight group were significantly lower compared to the Asthma group ( $\mathrm{p}=0.0001$ for both) as well as compared to the Overweight + Asthma group $(p=0.0001$ for both). The Asthma group had a significantly lower level of leptin compared to the Overweight $(\mathrm{p}=0.00001)$ and Overweight + Asthma groups $(p=0.00001)$. A positive bronchodilator test was associated significantly with Asthma as well as with Overweight+Asthma in comparison to Overweight [OR $=13,292$ $(4.54-38.95) 95 \% \mathrm{CI}]$ and $[\mathrm{OR}=12.891(4.25-$ 39.09) $95 \% \mathrm{CI}$, respectively. The same association was not found between the Asthma and Overweight + Asthma groups $(p=0.9562)$. The

Table1. General characteristics of the patients

\begin{tabular}{|c|c|c|c|c|}
\hline Parameter & $\begin{array}{c}\mathbf{O} \\
(\mathrm{N}=41)\end{array}$ & $\begin{array}{c}\text { A } \\
(\mathbf{N}=38)\end{array}$ & $\begin{array}{c}\mathbf{O}+\mathbf{A} \\
(\mathbf{N}=\mathbf{3 3})\end{array}$ & $\mathbf{P}$ \\
\hline \multicolumn{5}{|l|}{ Age } \\
\hline$\overline{\mathrm{X}} \pm \mathbf{S D}$ & $11.19 \pm 2.28$ & $10.74 \pm 2.77$ & $11.39 \pm 2.23$ & \multirow{3}{*}{${ }^{1} \mathrm{p}=0.4565$} \\
\hline Min/Max & $7 / 15$ & $7 / 17$ & $7 / 16$ & \\
\hline Median (IQR) & $11(9-13)$ & $10.5(8-13)$ & $12(10-13)$ & \\
\hline \multicolumn{5}{|l|}{ Sex } \\
\hline Male & $27(65.85 \%)$ & $23(60.53 \%)$ & $23(69.70 \%)$ & \multirow{2}{*}{${ }^{2} p=0.7162$} \\
\hline Female & $14(34.15 \%)$ & $15(39.47 \%)$ & $10(30.30 \%)$ & \\
\hline \multicolumn{5}{|l|}{ Family atopy } \\
\hline No & $21(51.22 \%)$ & $8(21.05$ & $5(15.15 \%)$ & \multirow{2}{*}{${ }^{2} \mathrm{p}=0.0011^{*}$} \\
\hline Yes & $20(48.78 \%)$ & $30(78.95 \%)$ & $28(84.85 \%)$ & \\
\hline \multicolumn{5}{|c|}{ Family history of DM } \\
\hline No & $30(7317 \%)$ & $30(78.95 \%)$ & $17(51.52 \%)$ & \multirow{2}{*}{${ }^{2} \mathrm{p}=0.0034^{*}$} \\
\hline Yes & $11(26.83 \%)$ & $8(21.05 \%)$ & $16(48.48 \%)$ & \\
\hline \multicolumn{5}{|l|}{ Premature birth } \\
\hline No & $32(78.05 \%)$ & $34(89.47 \%)$ & $31(93.94 \%)$ & \multirow{2}{*}{${ }^{3} \mathrm{p}=0.1115$} \\
\hline Yes & $9(21.95 \%)$ & $4(10.53 \%)$ & $2(6.06 \%)$ & \\
\hline \multicolumn{5}{|l|}{ Birth weight } \\
\hline$\leq 2.500$ & $2(4.9 \%)$ & $4(10.5 \%)$ & $0(0 \%)$ & \multirow{3}{*}{$\begin{array}{c}\mathrm{O} / \mathrm{O}+\mathrm{A}(\mathrm{p}=0.9456)^{\wedge} \\
\mathrm{O} / \mathrm{A}(\mathrm{p}=0.2092)^{\wedge} \\
\mathrm{A} / \mathrm{O}+\mathrm{A}(\mathrm{p}=0.2095)^{\wedge}\end{array}$} \\
\hline$>2.500<3.500$ & $17(41.5 \%)$ & $29(50 \%)$ & $15(45.5 \%)$ & \\
\hline$\geq 3.500$ & $22(53.7 \%)$ & $15(39.5 \%)$ & $18(54.5 \%)$ & \\
\hline \multicolumn{5}{|c|}{ Breast-feeding - months } \\
\hline None & $4(9.76 \%)$ & $5(13.16 \%)$ & $1(3.03 \%)$ & \multirow{4}{*}{$\begin{array}{c}\leq 4 \mathrm{M} />4 \leq 6 \mathrm{M} />6 \leq \\
12 \mathrm{M} \\
{ }^{2} \mathrm{p}=0.5371\end{array}$} \\
\hline$>1 \leq 4$ & $4(9.76 \%)$ & $1(2.63 \%)$ & $0(0 \%)$ & \\
\hline$>4 \leq 6$ & $10(24.39 \%)$ & $9(23.68 \%)$ & $9(27.27 \%)$ & \\
\hline$>6 \leq 12$ & $23(56.10 \%)$ & $23(60.53 \%)$ & $2(69.70 \%)$ & \\
\hline \multicolumn{5}{|c|}{ Positive history of passive smoking - number of smokers in the family } \\
\hline$\overline{\mathrm{X}} \pm \mathbf{S D}$ & $1.15 \pm 0.91$ & $0.87 \pm 0.81$ & $0.91 \pm 1.4$ & \multirow{3}{*}{${ }^{1} \mathrm{p}=0.0994$} \\
\hline $\operatorname{Min} / \operatorname{Max}$ & $0 / 4$ & $0 / 3$ & $0 / 7$ & \\
\hline Median (IQR) & $1(0-2)$ & $1(0-1)$ & $1(0-1)$ & \\
\hline & $\begin{array}{l}{ }^{*} \text { sig } \\
\text { lis } \mathrm{H} \text { test; }{ }^{2} \mathrm{P}\end{array}$ & $\begin{array}{l}\text { cant for } \mathrm{p}<0 \text {. } \\
\text { son Chi-squa }\end{array}$ & st; ${ }^{3}$ Yates & ion \\
\hline
\end{tabular}

$\mathrm{O}=$ overweight group; $\mathrm{A}=$ asthma group; $\mathrm{O}+\mathrm{A}=$ overweight + asthma group; $\overline{\mathrm{X}}=$ mean; $\mathrm{SD}=$ standard deviation ; $\mathrm{DM}=$ Diabetes mellitus 
Overweight group had the highest proportion of children with no SPT/CAP sensitization - 90.24\%. Polysensitization was present in asthma groups, with normal and high BMI in $52.63 \%$ and $52.63 \%$, respectively.

In all three groups, Overweight, Asthma, and Overweight+Asthma, a significant positive correlation was observed between leptin and BMI $(r=0.652 ; p=0.0001$ and $r=0.530 ; p=0.001$ and $\mathrm{r}=0.563 ; \mathrm{p}=0.001$, respectively) as well as between leptin and $\mathrm{WC}(\mathrm{r}=0.508 ; \mathrm{p}=0.001$ and $\mathrm{r}=0.426 ; \mathrm{p}=0.019$ and $\mathrm{r}=0.527 ; \mathrm{p}=0.002$, respectively). The correlation between leptin and WHR was not significant $(\mathrm{r}=0.063 ; \mathrm{p}=0.698$ and $\mathrm{r}=0.075 ; \mathrm{p}=0.693$ and $\mathrm{r}=0.034 ; \mathrm{p}=0.852$, respectively). We also found no significant correlations between leptin with atopy parameters [Eo, Ig$\mathrm{E}, \mathrm{SPT} / \mathrm{CAP}, \mathrm{Fe}(\mathrm{NO})]$ in all three of the analyzed groups (Table 3 ).

Table2. Analysis of leptin and atopy parameters according to a clinical diagnosis

\begin{tabular}{|c|c|c|c|c|}
\hline Parameters & $\begin{array}{c}O \\
(\mathrm{~N}=41)\end{array}$ & $\begin{array}{c}A \\
(N=38)\end{array}$ & $\begin{array}{c}\mathbf{O}+\mathbf{A} \\
(\mathbf{N}=\mathbf{3 3})\end{array}$ & $\mathbf{P}$ \\
\hline \multicolumn{5}{|l|}{ FEV1/VC } \\
\hline$\overline{\mathrm{X}} \pm \mathbf{S D}$ & $99.6 \pm 8.3$ & $99.5 \pm 9.7$ & $97.7 \pm 8.4$ & ${ }^{1} \mathrm{p}=0.4992$ \\
\hline \multicolumn{5}{|l|}{ Eo } \\
\hline$\overline{\mathrm{X}} \pm \mathbf{S D}$ & $2.8 \pm 2.5$ & $5.8 \pm 3.6$ & $5.1 \pm 2.8$ & \multirow{2}{*}{${ }^{1} \mathrm{p}=0.00001^{*}$} \\
\hline Median (IQR) & $1.9(1.1-3.7)$ & $5.7(3.1-8.0)$ & $5.4(2.3-6.9)$ & \\
\hline \multicolumn{5}{|l|}{ IgE } \\
\hline$\overline{\mathrm{X}} \pm \mathbf{S D}$ & $104.7 \pm 108.43$ & $388.7 \pm 412.8$ & $401.4 \pm 546.9$ & \multirow{2}{*}{${ }^{1} \mathrm{p}=0.00001^{*}$} \\
\hline Median (IQR) & 32.5 (8.6-109) & $208.5(112-674)$ & $221.5(105-409)$ & \\
\hline \multicolumn{5}{|l|}{$\mathrm{Fe}(\mathrm{NO})$} \\
\hline $\bar{X}_{ \pm \mathbf{S D}}$ & $16.1 \pm 10.5$ & $30.1 \pm 25.5$ & $30.8 \pm 26.9$ & \multirow{2}{*}{${ }^{1} \mathrm{p}=0.0366^{*}$} \\
\hline Median (IQR) & $13(9-19)$ & $25.5(10-38)$ & $20.5(14-45)$ & \\
\hline \multicolumn{5}{|l|}{ Leptin } \\
\hline $\bar{X} \pm \mathbf{S D}$ & $30.6 \pm 21.6$ & $9.2 \pm 16.2$ & $31.1 \pm 20.3$ & \multirow{2}{*}{${ }^{1} \mathrm{p}=0.0374 *$} \\
\hline Median (IQR) & $90.4(1.1-15.3)$ & $101(1.2-2.3)$ & $98.4(1.5 \pm 20.1)$ & \\
\hline \multicolumn{5}{|l|}{ Bronchodilator test } \\
\hline Negative & $33(80.49 \%)$ & $9(23.68 \%)$ & $8(23.24 \%)$ & \multirow{2}{*}{${ }^{2} \mathrm{p}=0.00001$} \\
\hline Positive & $8(19.51 \%)$ & $29(76.32 \%)$ & $25(75.76 \%)$ & \\
\hline \multicolumn{5}{|l|}{ SPT/CAP } \\
\hline Negative & $37(90.24 \%)$ & $4(10.53 \%)$ & $7(21.21 \%)$ & \multirow{3}{*}{$\begin{array}{c}\mathrm{A} / \mathrm{A}+\mathrm{O} \\
{ }^{2} \mathrm{p}=0.4055\end{array}$} \\
\hline Monosensitized & $0(0 \%)$ & $14(36.84 \%)$ & $9(27.27 \%)$ & \\
\hline Polysensitized & $4(9.76 \%)$ & $20(52.63 \%)$ & $17(51.51 \%)$ & \\
\hline & ${ }^{*}{ }_{\mathrm{si}}$ & $\begin{array}{l}\text { ant for } \mathrm{p}<0.05 \\
\text { st; }{ }^{2} \text { Pearson Chi- }\end{array}$ & are test & \\
\hline
\end{tabular}

$\mathrm{O}=$ overweight group; $\mathrm{A}=$ asthma group; $\mathrm{O}+\mathrm{A}=$ overweight + asthma group; $\mathrm{X}=$ mean; $\mathrm{SD}=$ standard deviation; $\mathrm{FEV} 1 /$ $\mathrm{FVC}=$ ratio of forced expiratory volume in the first second and forced vital capacity; Eo=eosinophil; $\mathrm{Fe}(\mathrm{NO})=$ fractional exiled nitric oxide, $\mathrm{SPT}=$ skin prick test; $\mathrm{CAP}=$ antigen specific $\mathrm{IgE}$ antibodies 
Table 3. Correlation between Leptin and parameters for atopy, obesity, and abdominal obesity

\begin{tabular}{|c|c|c|c|}
\hline \multirow{2}{*}{ Parameters } & \multicolumn{3}{|c|}{ Correlations - Leptin } \\
\hline & $O(N=41)$ & $A(N=38)$ & $\mathrm{O}+\mathrm{A}(\mathrm{N}=\mathbf{3 3})$ \\
\hline \multicolumn{4}{|c|}{ Obesity and abdominal obesity parameters } \\
\hline BMI & $r(39)=0.652 ; p=0.000^{*}$ & $r(36)=0.530 ; p=0.001 *$ & $r(31)=0.563 ; p=0.001 *$ \\
\hline WC & $r(38)=0.508 ; p=0.001 *$ & $r(28)=0.426 ; p=0.019^{*}$ & $r(31)=0.527 ; p=0.002 *$ \\
\hline WHR & $\mathrm{r}(38)=0.063 ; \mathrm{p}=0.698$ & $\mathrm{r}(28)=0.075 ; \mathrm{p}=0.693$ & $\mathrm{r}(31)=0.034 ; \mathrm{p}=0.852$ \\
\hline \multicolumn{4}{|c|}{ Atopy parameters } \\
\hline Eo & $r(41)=0.109 ; p=0.498$ & $\mathrm{r}(38)=0.239 ; \mathrm{p}=0.149$ & $\mathrm{r}(33)=0.274 ; \mathrm{p}=0.123$ \\
\hline IgE & $r(41)=0.090 ; p=0.575$ & $r(38)=0.045 ; p=0.788$ & $r(33)=0.239 ; p=0.188$ \\
\hline SPT/CAP & $r(41)=0.053 ; p=0.744$ & $\mathrm{r}(38)=0.249 ; \mathrm{p}=0.131$ & $r(33)=0.044 ; p=0.806$ \\
\hline $\mathrm{Fe}(\mathrm{NO})$ & $r(41)=0.146 ; p=0.440$ & $\mathrm{r}(38)=0.202 ; \mathrm{p}=0.302$ & $\mathrm{r}(33)=0.110 ; \mathrm{p}=0.593$ \\
\hline
\end{tabular}

$\mathrm{O}=$ overweight group; $\mathrm{A}=$ asthma group; $\mathrm{O}+\mathrm{A}=$ overweight + asthma group; $\mathrm{BMI}=$ body mass index; $\mathrm{WC}=$ waist circumference; $\mathrm{WHR}=$ waist to hip ratio; $\mathrm{Eo}=$ eosinophil; $\mathrm{SPT}=$ skin prick test; $\mathrm{CAP}=$ antigen specific $\mathrm{IgE}$ antibodies; $\mathrm{Fe}$ $(\mathrm{NO})=$ fractional exiled nitric oxide

\section{DISCUSSION}

Asthma and obesity are conditions that often coexist, and their association in numerous studies has been confirmed. [23, 24, 25, 26] Obesity increases the risk of asthma in both sexes in children and adults of different ethnic groups. Potential underlying mechanisms include a shared genetic component, dietary and nutritional factors, physical inactivity, chronic systemic inflammation, metabolic abnormalities, and changes in lung anatomy and function. A Th1 immune response in obesity and a Th2 immune response in asthma are two different immune mechanisms of inflammation that underlie these two chronic conditions. After their activation, cascade reactions of effector cells and cytokines occur that are supposed to inhibit each other. In adults, asthma in obese asthmatics is mainly non-atopic and neutrophil-mediated. Although childhood asthma is more than $80 \%$ atopic, the association of childhood asthma and obesity exists with or without atopy. [29, 30]

In our study, familial atopy was significantly more associated with asthma groups compared to the overweight group. There was no statistically significant difference between asthmatic children with normal and high BMI. Also, there was no statistically significant difference between children in the asthma groups, in terms of Eo, IgE antibodies, $\mathrm{Fe}(\mathrm{NO})$, and positive SPT/ CAP. These findings confirmed the atopic basis of pediatric asthma. However, atopy as a mechanism of the association between asthma and being overweight was not documented. This is in concordance with the results reported by Henkin et al. [31] and contrary to the results from the study by Papoutsakis et al. [32] In the third phase of the ISAAC study in Macedonia, Vlaski et al. [4] have reported a male-specific positive association between being overweight and dry night cough and thus being diagnosed with asthma. No association was found between BMI and other asthma symptoms in Vlaski et al. [4] Atopy, however, was not considered for this study. Other studies have suggested a positive association between being overweight and allergic symptoms with high serum IgE antibody levels as a marker of atopy. Visness et al. [33] observed a positive and stronger association with nutritional allergies in overweight American children and adolescents aged 2 to 19 years. The analysis of our data documented an increased level of $\mathrm{Fe}(\mathrm{NO})$ in $20 \%$ of the overweight children. This finding may be due to an impaired regulation of the inflammatory mechanisms of the lungs in overweight children. Several studies have reported a significant correlation between $\mathrm{Fe}(\mathrm{NO})$ and age, sex, and BMI in healthy children and adults. [34, 35] 
Adipose tissue is a metabolic and endocrine organ responsible for storage of energy and secretions of biologically active molecules - adipokines (leptin and adiponectin), cytokines - interleukin-6 (IL-6), and tumor necrotizing factor (TNF-alfa), which in turn can have significant effects on metabolism and inflammation. [36] The function of the main adipokine, leptin, is to regulate appetite, energy balance, fat deposition, glucose homeostasis, lipid metabolism, insulin sensitivity, angiogenesis, inflammation processes, and blood pressure. [37] Additionally, in human lungs, it stimulates and maintenances inflammation. Increased macrophage production of TNF- $\alpha$, IL- 6 , and IL-12 is part of up-regulation and redirection of the Th1 immune response. [38] Serum leptin levels are relatively low in pre-pubertal ages, and these levels show a gradual increase in both sexes before the onset of puberty. [39, 40, 41] During puberty, leptin levels increase significantly in girls and decrease in boys. [42, 43]

Our results showed higher serum leptin levels in overweight children, in both groups, with and without asthma, compared to the children with a normal BMI. This was consistent with other studies. $[39,44]$ However, there are studies that document higher leptin levels in non-obese asthmatic pre-pubescent boys. [45, 46] Leptin might be an underlying mechanism of pediatric asthma, and this might partly explain the higher prevalence of asthma in the first decade of life for males. Despite the higher symptom score in overweight asthmatic children later in life, Yuksel et al. [47] in their study, show a correlation between leptin levels and symptom scores in normal weight children with asthma. This finding confirms the role of leptin as an inflammatory mediator in asthma, regardless of obesity.

BMI is the most commonly used parameter to determine obesity. However, Appleton et al. [48] and Kronander et al. [49] have reported that abdominal obesity was even more associated with asthma and used WC and WHR as abdominal, central obesity parameters. In this study, we did not examine the influence of sex and age of the children on the correlation between obesity parameters and serum leptin levels in the groups. This was done because of the small sample size, which was one limitation. In all three groups, leptin levels had a significant linear correlation only with BMI and WC. Bustos et al. [50] have confirmed leptin association with BMI, but not with WC. Moreover, metabolic syndrome is associated with $\mathrm{WC}$ values, regardless of BMI. [51]

We found that a family history of diabetes mellitus was significantly more present in overweight asthmatics compared to asthmatic children with normal BMI.

Perinatal factors have been found to be involved in the pathogenesis of obesity and asthma later in life. Breast-feeding has been reported to protect asthma development, but only during early childhood. [52, 53] Infants who were exclusively breast-fed have also been observed to be protected from overweight. [54, 55, 56] In our study, no significant association of premature birth, positive history of passive smoking, or duration of breast-feeding with asthma and/ or obesity was found. The largest percentage of children in the three groups was breast-fed for between 6-12 months.

Regarding birth weight, most of studies have noted that high birth weight (LGA $\geq 4000$ g) has been associated with an increased percentage of body fat in older children. [57] Low birth weight has been reported to be associated with a higher risk of asthma, but its association with obesity has been inconsistent. Some studies have indicated a reduced risk for obesity by low birth weight, some studies have not shown an association, and some studies have shown a positive association between these factors. [58, 59] Kocova et al. [39] have reported a vulnerability for metabolic syndrome later in life in SGA infants. In our study, no significant difference was found between the groups related to the birth weight, although the proportion of patients with birth weight $\geq 3.500$ g. was higher in overweight groups compared to asthma group.

In discussing the connection between asthma and obesity, mechanical mechanisms play an important role. Adipose tissue in overweight patients, even more in obese patients, mechanically affects the respiratory system, thereby decreasing pulmonary and chest elasticity in asthmatic or non-asthmatic children. The most consistent alteration is related to functional residual capacity (FRC) reduction. We did not find a significant difference between the groups related to FEV1/VC. 


\section{CONCLUSION}

Atopy as an underlying mechanism of the association between asthma and being overweight was not confirmed. Leptin showed a significantly linear strong correlation with BMI and WC, but not with WHR as marker of central obesity in all three groups. More studies are needed in the future to clarify the association between leptin, abdominal obesity and asthma.

\section{REFERENCES}

1. Masoli M, Fabian D, Holt S, Beasley R. Global Initiative for Asthma (GINA) Program The global burden of asthma: executive summary of the GINA Dissemination Committee report. Allergy 2004; 59:469-78.

2. Влашки Е., Ставриќ К., Сечкова Л. и сор. Преваленција и тежина на астма, алергиски ринит и егзема кај школските деца во Скопје (Интернационална студија за астма и алергии во детството, фаза 3). Мак Спи Мед 2005; 51(1-2):11-23.

3. Vlaski E, Stavrikj K, Kimovska M, Cvejoska Cholakovska V, Lawson J. Divergent trends in the prevalence of asthma-like symptoms and asthma in a developing country: three repeated surveys between 2002 and 2016. Allergol et Immunopathol (Madr) 2020;48(5):475-83.

4. Vlaski E, Stavric K, Isjanovska R, et al. Overweight hypothesis in asthma and eczema in young adolescents. Allergol et Immunopathol (Madr) 2006;34(5):199-205.

5. Obesity and overweight. World Health Statistics 2017. WHO

6. Vlashki E. Cvejoska Colakovska V, Kimovska $\mathrm{M}$, et al. Body mass index and risk of asthma and asthma-like symptoms in childhood [abstract]. In: Proceedings of the Annual Congress of the European Academy of Allergology and Clinical Immunology 2017 June 17-21, Helsinki, Finland: EAACI; 2017. Abstract nr 1166.

7. Permaul P, Kanchongkittiphon W, Phipatanakul W. Childhood asthma and obesity-what is the true link? Ann Allergy Asthma Immunol. 2014; 113(3):244-46.

8. Peters L, McKinney JM, Smith B, et al. Impact of obesity in asthma: evidence from a large prospective disease management study. Ann Allergy Asthma Immunol 2011;106:30-35
9. Ferrante AW Jr. Obesity-induced inflammation: a metabolic dialogue in the language of inflammation. J Intern Med 2007;262:408-14

10. Bruunsgaard H, Pedersen BK. Age-related inflammatory cytokines and disease. Immunol Allergy Clin North Am. 2003;23:15-39.

11. Maffei M, Halaas J, Ravussin E, et al. Leptin levels in human and rodent: measurement of plasma leptin and ob RNA in obese and weight-reduced subjects. Nat Med 1995;1:1155-1161.

12. Erhardt E, Foraita R, Pigeot I et al. Reference values for leptin, adiponectin in children below the age of 10 based on the IDEFICS cohort. International J Obesity 2014;38:532-538.

13. Cole TJ, Bellizzi MC, Flegal KM, Dietz WH. Establishing a standard definition for child overweight and obesity worldwide: international survey. BMJ 2000;320:1240-3.

14. Waist Circumference and Waist-Hip Ratio, Report of a WHO Expert Consultation". WHO 8-11 December 2008. Retrieved March 21, 2012.

15. Peter Schwandt and Gerda-Maria Haas. Waist Circumference in Children and Adolescents from Different Ethnicities. Childhood obesity ISBN 978-953-51-0374-5. 2012;79-94.

16. Yunginger JW. Clinical significance of $\operatorname{IgE}$, In: Middleton E, et al editors. Allergy principles and practice 1988;2:849-60.

17. Hoffman DR. Comparison of methods of performing the radioallergosorbent test: Phadebas, Fada-Nalebuff and Hoffman protocols. Ann Allergy 1980;45:343-6.

18. Bouscquet J, Heinzerling L, Bachert C, et al. Practical guide to skin prick tests in allergy to aeroallergens. Allergy 2012;67:18-24.

19. Standardization of Spirometry, 1994 Update. American Thoracic Society. Am J Respir Crit Care Med 1995;152(3):1107-36.

20. American Thoracic Society: Guidelines for Methacholine and Exercise Challenge Testing. Am J Respir Crit Care Med 2000;161:309-29.

21. Минов J. Спирометрија. Минов J. Во: Респираторен систем - функционална дијагностика. Пристоп МК, Скопје 2010,4981.

22. American Thoracic Society Clinical Practice Guidelines: Interpretation of Exhaled Nitric Oxide Levels (FENO) for Clinical Applications. Am J Respir Crit Care Med 2011;184:602-15.

23. Flaherman V, Rutherford GW. A meta-analysis of the effect of high weight on asthma. Arch Dis Child 2006; 91: 334-339.

24. Lang JE. Obesity, Nutrition, and Asthma in Children. Pediatric allergy, immunology, and pulmonology. 2012 Jun; 25(2):64-75.

25. Mamun AA, Lawlor DA, Alati R, O'Callaghan MJ, Williams GM,Najman JM. Increasing body mass index from age 5 to 14 years predicts asth- 
ma among adolescents: evidence from a birth cohort study. Int J Obesity 2007; 31: 578-583.

26. Gilliland FD, Berhane K, Islam T, et al. Obesity and the risk of newly diagnosed asthma in school-age children. Am J Epidemiol 2003; 158: 406-415.

27. Azizpour et al. Effect of childhood BMI on asthma: a systematic review and meta-analysis of case-control studies.BMC Pediatr 2018;18(1)143. doi:10.1186/s12887-018-1093-z.

28. Scott HA, Gibson PG, Garg ML, Wood LG. Airway inflammation is augmented by obesity and fatty acids in asthma. Eur Respir J 2011;38:594602.

29. Visness CM, London SJ, Daniels JL, et al. Association of childhood obesity with atopic and nonatopic asthma: results from the National Health and Nutrition Examination Survey 19992006. J Asthma 2010;47:822-9.

30. Von Mutius EV, Schwartz J, Neas LM, Dockery D, Weis ST. Relation of body mass index to asthma and atopy in children: NHNES Study III. Thorax 2001;56:835-8.

31. Henkin S, Brugge D, Bermudez $\mathrm{O}$ et al. A case-control study of body mass index and asthma in Asian children. Ann of Allergy Asthma Immunol. 2008;100:447-451.

32. Papoutsakis C, Chondronikola M, Antonogeorgos $\mathrm{G}$ et al. Associations between central obesity and asthma in children and adolescents: a case control study. J Asthma 2015;52(2):128-134.

33. Visness C, London S, Daniels J et al. Association of Obesity with IgE and Allergy Symptoms in Children and Adolescents: Results from NHANES 2005-2006. J Allergy Clin Immunol 2009 ;123(5):1163-1169.

34. Baraldi E, de Jongste JC. Measurement of exhaled nitic oxide in children. Eur Respir J 2002;20:223-37.

35. Franklin P, Taplin R, Stick S. A community study of exhaled nitric oxide in healthy children. Am J Respir Crit Care Med 1999;159:69-72.

36. Ferrante AW Jr. Obesity-induced inflammation: a metabolic dialogue in the language of inflammation. J Intern Med 2007;262:408-14.

37. Maffei M, Halaas J, Ravussin E, et al. Leptin levels in human and rodent: measurement of plasma leptin and ob RNA in obese and weight-reduced subjects. Nat Med 1995;1:1155-1161.

38. Loffreda S, Yang SQ, Lin HZ, et al. Leptin regulates proinflammatory immune responses. FASEB J 1998;12:57-65.

39. Kocova M, Sukarova-Angelovska E, Tanaskos$\mathrm{ka} \mathrm{M}$ et al. Metabolic setup and risks in obese children. J Med Biochem 2015;34(1):31-7

40. Palchevska S, Krstesvska M, Shukarova E, et al. Comparing preterm and term newborns serum adiponectin and leptin concentrations and their correlations with anthropometric parameters Macedonian Journal of Medical Sciences 2012;5(3):317-323.

41. Palchevska S, Aluloska N, Krstevska M, et al. Correlation of serum adiponectin and leptin concentrations with anthropometric parameters in newborns. Srpski Archiv za Celokupno Lekarstvo 2012;140(9-10):595-9.

42. Blum WF, Englaro P, Hanitsch S, et al. Plasma leptin levels in healthy children and adolescents: dependence on body mass index, body fat mass, gender, pubertal stage and testosterone. J Clin Endocrinol Metab 1997;82:2904-10.

43. Garcia-Mayor RV, Andrade MA, Rios M, Lage M, Dieguez C, Casanueva FF. Serum leptin levels in normal children: relationship to age, gender, body mass index, pituitary-gonadal hormones, and pubertal

44. stage. J Clin Endocrinol Metab 1997;82:284955.

45. Lugogo N, Bappanad, Kraft M. Obesity, metabolic dysregulation, and oxidative stress in asthma. Biochem Biophys Acta 2011;1810:11201126.

46. Guler N, Kirerleri E, Ones U, et al. Leptin: does it have any role in childhood asthma? J Allergy Clin Immunol 2004:114:254-9.

47. Nagel G, Koenig W, Rapp K, et al. Associations of adipokines with asthma, rhino conjunctivitis, and eczema in German schoolchildren. Pediatric Allergy Immunol 2009; 20: 81-88.

48. Yuksel H, Sogut A, Yilmaxz O et al. Role of adipokines and hormones on obesity in childhood asthma. Allergy Asthma Immunol Res 2012;4(2):98-103.

49. Appleton SL, Adams RJ, Wilson DH, Taylor AW, Ruffin RE; North West Adelaide Health Study Team. Central obesity is associated with nonatopic but not atopic asthma in a representative population sample. J Allergy Clin Immunol 2006;118:1284-1291.

50. Appleton SL, Adams RJ, Wilson DH, et al. Central obesity is associated with nonatopic but not atopic asthma in a representative population sample. J Allergy Clin Immunol 2006;118:12841291.

51. Bustos P, Amigo H, Oyarzun M, Rona RJ. Is there a causal relation between obesity and asthma? Evidence from Chile. Int J Obes Relat Metab Disord 2005;29:804-9.

52. Janssen I, Katzmarzyk P, Ross R. Waist circumference and not body mass index explains obesity-related health risk. Am J Clin Nutr 2004;79:379-84.

53. Bronwyn KB, Kull I, Garden F, et al. Breastfeeding, asthma and allergy: a tale of two cities. Pediatr Allergy Immunol 2012; 23: 75-82. 
54. Tarrant M, Kwok MK, Lam TH, et al. Breast-feeding and childhood hospitalizations for infections. Epidemiology 2010; 21: 947-54.

55. Gillmann MW, Rifas-Shiman SL, Camargo CA, et al. Risk of overweight among adolescents who were breastfed as infants. JAMA 2001;285:2461-7.

56. Fiocchi AG, Martelli A, De Chiara A, et al. Primary dietary prevention of food allergy. Ann Allergy Asthma Immunol. 2003; 91(1): 3-12.

57. Jwa SC, Fujiwara T, Kondo N. Latent protective effects of breastfeeding on late childhood overweight and obesity: A nationwide prospective study. J Obes 2014;22:1527-1537.
58. Schellong K, Schulz S, Harder T, Plagemann A. Birth weight and long-term overweight risk: systematic review and a meta-analysis including 643,902 persons from 66 studies and 26 countries globally. PloS One 2012; 7: e47776.

59. Oldroyd J, Renzaho A, Skouteris H. Low and high birth weight as risk factors for obesity among 4 to 5-year-old Australian children: does gender matter? Eur J Pediatr 2011;170:899-906.

60. Rugholm S, Baker JL, Olsen LW, et al. Stability of the association between birth weight and childhood overweight during the development of the obesity epidemic. Obes Res 2005; 13: 2187-2194.

\title{
Резиме
}

\section{ЛЕПТИН, ПАРАМЕТРИ ЗА ДЕБЕЛИНА И АТОПИЈА КАЈ ДЕЦА СО АСТМА}

\author{
Валентина Цвејоска Чолаковска ${ }^{1}$ Емилија Влашки ${ }^{1}$, \\ Мирјана Кочова ${ }^{2}$, Весна Велиќ Стефановска ${ }^{3}$, Александар Петличковски ${ }^{4}$
}

${ }^{1}$ Оддел за пулмологија и алергологија, Универзитетска клиника за детски болести, Медицински факултет, Универзитет „Св. Кирил и Методиј“, Скопје, РС Македонија

${ }^{2}$ Оддел за ендокринологија и генетика, Универзитетска клиника за детски болести, Медицински факултет, Универзитет „Св. Кирил и Методиј“, Скопје, РС Македонија

${ }^{3}$ Институт за епидемиологија и биостатистика со медицинска информатика, Медицински факултет, Универзитет „Св. Кирил и Методиј“, Скопје, РС Македонија

${ }^{4}$ Институт за имунобиологија и хумана генетија, Медицински факултет, Универзитет „Св. Кирил и Методиј“, Скопје, РС Македонија

Лептинот, како главен адипокин, позитивно корелира со масното ткиво во телото, а пак, атопијата е важна во развојот на детската астма. Нашата главна цел беше да ја испитаме асоцираноста меѓу лептинот, параметрите за дебелина и атопија кај децата со астма. Беа вклучени 122 деца (73 момчиња, 39 девојчиња, средна возраст 11,1 $\pm 2,4)$, од кои 41 беше натхрането, 38 имаа астма и нормален индекс на телесна маса (BMI) и 33 беа натхранети со астма. Беше одредувано нивото на серумски лептин, BMI, обемот на струкот (WC) и односот половина - колкови (waist to hips ratio WHR). Кај секое дете се изведуваше кожен прик-тест/специфични серумски IgE антитела (SPT/CAP), вкупен серумски IgE, фракциониран издишан азотен моноксид (FeNO) и белодробни функционални тестови. Средната вредност на лептинот беше 9,2 $\pm 16,2 \mathrm{ng} / \mathrm{ml}$ кај децата со астма, 30,6 $\pm 21,6 \mathrm{ng} / \mathrm{ml}$ кај натхранетите деца и $31,1 \pm 20,3 \mathrm{ng} / \mathrm{ml}$ кај натхранетите деца со атсма, со статистички значајна разлика меѓу групите $(\mathrm{p}=0,0374)$, со сигнификантно пониско ниво во групата на деца со астма во однос на групите со натхранети деца, со астма $(\mathrm{p}=0,00001)$ или без астма $(\mathrm{p}=0,00001)$. BMI и WC сигнификантно позитивно корелираат со нивото на лептинот кај децата во сите три групи (за BMI r $=0,652$ vs. $r=0,30$ vs. $r=0,563$, следствено и за $\mathrm{WC} r=0,508$ vs. $r=0,426$ vs. $r=0,527$, соодветно). Не беше утврдена сигифигантна корелација меѓу нивото на лептинот и параметрите за атопија (Ео, $\mathrm{IgE}, \mathrm{SPT} / \mathrm{CAP}, \mathrm{FeNO})$ кај сите три испитувани групи ( $>$ > 0,05).

Атопијата, како механизам на асоцираност меѓу астмата и натхранетоста, не беше потврдена. Лептинот сигнификантно линеарно корелираше со BMI и WC во сите испитувани групи, но не и со WHR, како параметар за централна дебелина.

Клучни зборови: астма, дебелина, деца, индекс на телесна маса, лептин, натхранетост 